\title{
LESÃO DO COLO DE MUDAS DE ABACATEIRO POR
} TEMPERATURA ELEVADA $\left.{ }^{(}\right)$. Tarcizo Toledo Carnaúba e Altino Aldo ORTolani. Durante a formação de pomar de abacateiro, nas regiões tropicais e mesmo nas subtropicais do Estado de São Paulo, tem sido observada a perda de mudas causada por uma lesão do caule, com características típicas de queimadura. As observações de campo mostram que a lesão embora ocorra junto ao ponto de enxertia, dificilmente danifica o porta-enxêrto. $\mathrm{O}$ início de danos é sempre observado no lado norte e poente. Alguns dias após, a lesão se estende e chega a abranger quase tôda a periferia da haste, numa faixa de 2 a $3 \mathrm{~cm}$. Êsses sintomas são semelhantes aos descritos por Franco $\left({ }^{2}\right)$, para cafeeiros novos. A utilização de proteção do caule de abacateiros jovens, contra a insolação, em pomares da California, é prática comum nos meses mais quentes do ano $\left({ }^{3,4}\right)$.

O presente trabalho apresenta os resultados observados em mudas de abacateiros submetidas a temperaturas elevadas e controladas em laboratório, a fim de se verificar os níveis térmicos letais e de possibilitar comparação com as condições normais de campo.

Material e método - Foram testadas 40 mudas de abacateiro da variedade Collinson, enxertadas sôbre cavalos provenientes de sementes da variedade Nabal, cultivadas em laminados, em condições normais de ripado. Para o aquecimento artificial do caule, foi utilizada lâmpada de raios infra-vermelhos, de $250 \mathrm{~W}$. O foco da lâmpada era dirigido para a parte inferior do caule, de modo a aquecer sòmente o porta-enxêrto e parte do enxêrto. A parte superior do caule bem como as fôlhas foi protegida com um anteparo termo-isolante (figura 1 ).

A medição da temperatura do caule se fêz por meio de par termoelétrico cobre constantan, $n .^{\circ} 30$. A milivoltagem foi tomada em um pontenciômetro da Leeds and Northrup. A junção termoelétrica foi inserida na superfície externa do tecido do caule, segundo método utilizado por Waggoner and Shaw $\left(^{5}\right)$.

A exposição aos raios infra-vermelhos durou 120 minutos, inclusive 25-30 minutos para a elevação da temperatura inicial até o nível constante adotado em cada tratamento estudado (figura 2).

Os tratamentos corresponderam às temperaturas de 35,40 , 42,45 e $48^{\circ} \mathrm{C}$, para as mudas enxertadas, e a 45 e $50^{\circ} \mathrm{C}$, para porta-enxêrto, todos com cinco repetições.

(1) Recebida para publicação a 8 de junho de 1966.

(2) Franco, coaracy Moraes. Lesão do colo do cafeeiro, causada pelo calor. Bragantia 20:[645]:652. 1961.

(3) YARICK, B. E. Care of little trees. Yearb. Calif. Avocado Soc. 1951, p. 79-83.

(4) WHITE, F. A. Care and protection of young avocado trees. Yearb. Calif. Avocado Soc. 1949 , p. $77-81$.

(5) WAGGONER, P. E. and SHAW, R. H. Temperature of potato and tomato leaves. Plant Physiol, 27(4):710-713. 1952. 


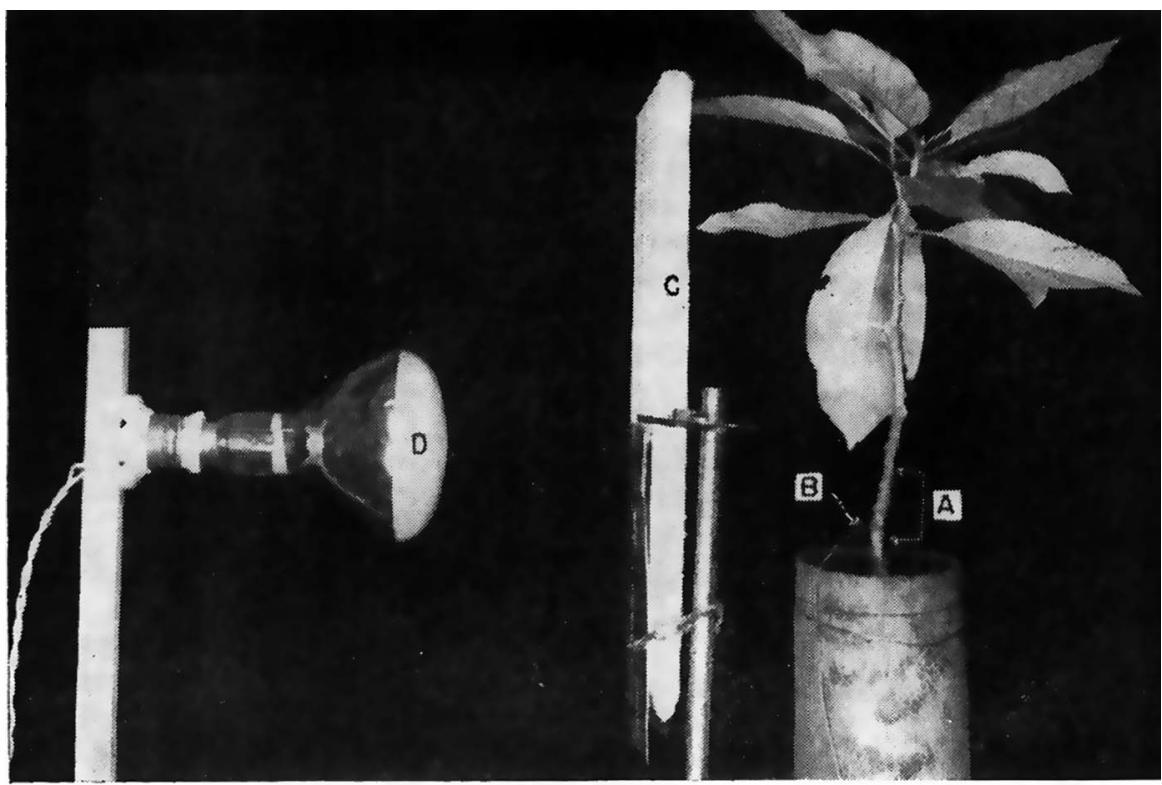

Frgura 1. - Exposição do caule de abacateiro à radiação térmica. $A$ - Parte do caule exposta à radiação; $B$ - Par termoelétrico; $C$ - Anteparo termo-isolante; $D$ - Lâmpada de $250 \mathrm{~W}$.

Resultados e conclusões - As observações, feitas após terem sido decorridos 30 dias dos respectivos tratamentos, revelaram que os caules das mudas enxertadas resistiram bem, não tendo sido notadas lesões; quando submetidos às temperaturas de 35,40 e até $42^{\circ} \mathrm{C}$, o aspecto das plantas era normal (quadro 1).

Com o tratamento de $44^{\circ} \mathrm{C}$, ocorreram danificações em quatro caules de enxertos, com queimaduras semicirculares. Essas mudas, de números 16, 17, 18 e 19, apresentaram normais o porta-enxêrto e a parte aérea. Nos tratamentos de 45 e $48^{\circ} \mathrm{C}$ tôdas as mudas morreram. As de números 21 e 25 , submetidas a $45^{\circ} \mathrm{C}$, embora tendo os enxertos mortos, mostraram que os porta-enxertos resistem a essa temperatura. O mesmo não ocorreu com as mudas de números 26 a 30 , submetidas a $48^{\circ} \mathrm{C}$, as quais tiveram danificados tanto o enxêrto como o porta-enxêrto. Os dados obtidos com porta-enxertos, de números 31 a 40 , confirmaram os resultados dos dois tratamentos anteriores.

Em estudos de geotermia, efetuados na Estação Experimental de Ribeirão Prêto $\left({ }^{6}\right)$, foram observadas ocorrências, em condições de campo, de temperaturas superiores a $48^{\circ} \mathrm{C}$, na superfície do solo. 


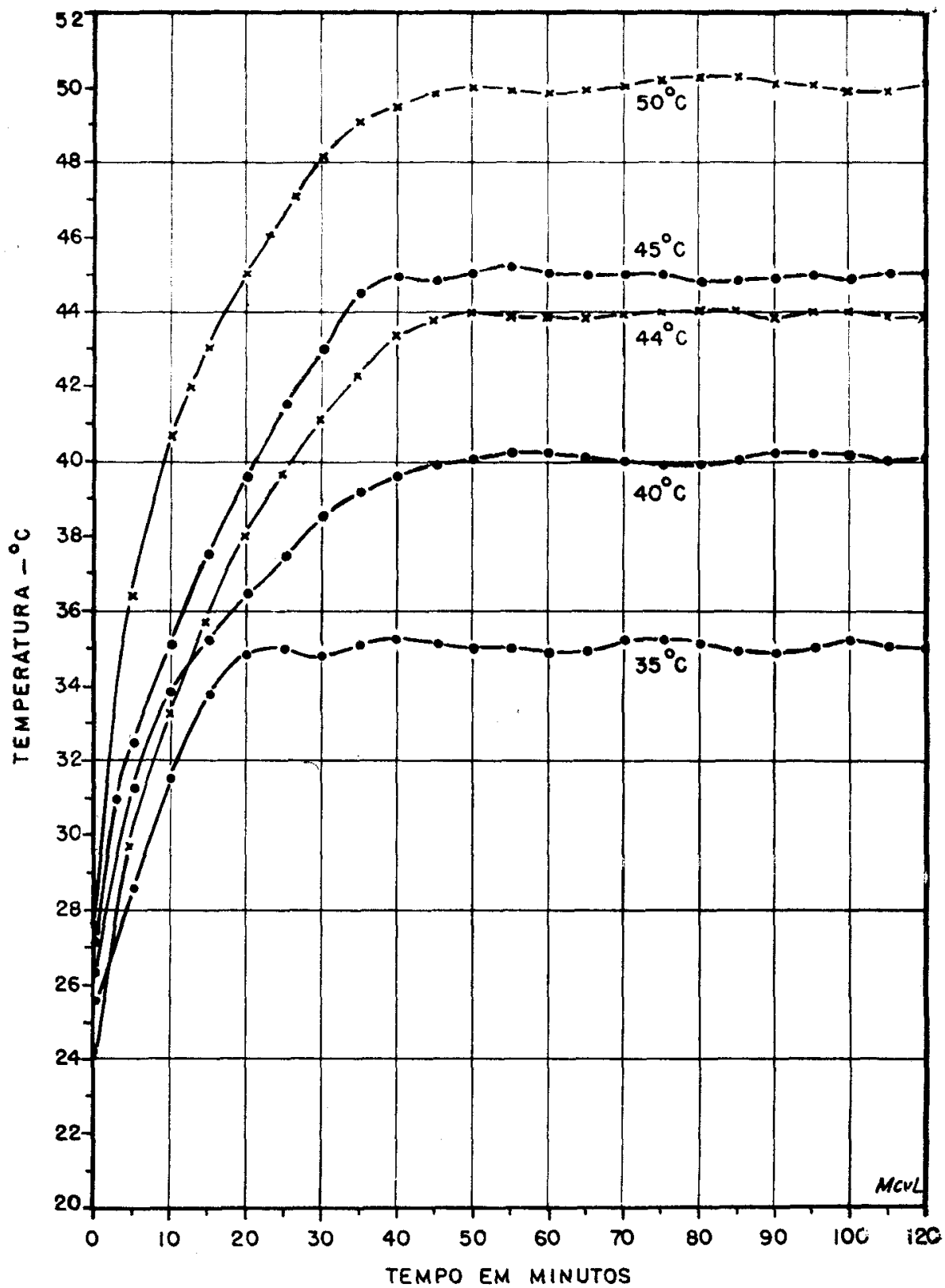

Figura 2, - Curvas da elevação das temperaturas de caules, para tratamento de $35,40,44,45$ e $50^{\circ} \mathrm{C}$. 
QUADro 1. - Resultados dos tratamentos, em laboratório, do caule de mudas de abacateiro, de enxertos e de porta-enxertos. às temperaturas de $35,40,42,44$, 45,48 e $50^{\circ} \mathrm{C}$

\begin{tabular}{|c|c|c|c|}
\hline \multicolumn{2}{|c|}{ Tratamentos } & \multicolumn{2}{|c|}{$\begin{array}{l}\text { Observacões das mudas após } 30 \\
\text { dias da data do tratamento }\end{array}$} \\
\hline Número e tipo de muda & $\begin{array}{l}\text { Temperatura. } \\
\text { do caule }{ }^{\circ} \mathrm{C}\end{array}$ & Enxêrto & Porta-enxèrıo \\
\hline 1 a 5 (enxertada) & $35 \quad \ldots \ldots \ldots$ & norriais & normais \\
\hline 6 a 10 (enxertada) $\ldots \ldots \ldots \ldots$ & $\ldots \ldots \ldots$ & normais & normais \\
\hline 11 a 15 (enxertada) & $\ldots \ldots$ & norniais & normais \\
\hline 16 a 20 (enxertada) & $\ldots \ldots \ldots$ & $\begin{array}{r}4 \text { danificados } \\
1 \text { nermal }\end{array}$ & nornuais \\
\hline 21 a 25 (enxertada) & $\ldots \ldots$ & mortos & norniais \\
\hline 26 a 30 (enxertada) & $\ldots \ldots \ldots$ & mortos & danificados \\
\hline 31 a 35 (porta-enxêrto) & $\ldots \ldots \ldots$ & - & normais \\
\hline 36 a 40 (porta-enxêrto) & $\ldots \therefore \ldots$ & - & mortus \\
\hline
\end{tabular}

Ensaio microclimático executado na Estação Experimental de Limeira (") mostrou que em solo nu, a $5 \mathrm{~cm}$ de profundidade, em dia claro de verão, a temperatura ultrapassa a $45^{\circ} \mathrm{C}$. Dados complementares $\left(^{8}\right)$ dêsse ensaio dão idéia de frequiência de temperatura máxima do ar a $5 \mathrm{~cm}$ de altura sôbre o solo nu. Em 200 dias de observação, no período de setembro de 1959 a abril de 1960 , foram anotados 90 dias com máximas iguais ou superiores a $40^{\circ} \mathrm{C}$, bem como 25 dias com máximas superiores a $45^{\circ} \mathrm{C}$. Waggoner and Shaw $\left({ }^{2}\right)$ observaram que fôlhas expostas à radiação, em dias claros, estavam com temperaturas de 3,3 a $8^{\circ} \mathrm{C}$, mais elevadas que as do ar, no mesmo nível.

Essas investigações de campo, associadas aos dados obtidos no presente trabalho, em condições de laboratório, evidenciam que - superaquecimento na camada microclimática próxima ao solo, pode causar a lesão do caule de mudas de abacateiro. SEÇÃO DE FRUTAS TROPICAIS E SEÇÃO DE CLIMATOLOGIA AGRÍCOLA, INSTITUTO AGRONÔMICO DO ESTADO DE SÃO PAULO.

(') Camargo, A. Paes De, Ortolani, A. A., Rodrigues, Ody e Godoy, H. Efeito de cobertura do terreno em laranjal sôbre as temperaturas extremas do ar. Bragantia 20:[XI]-XVII. 1961.

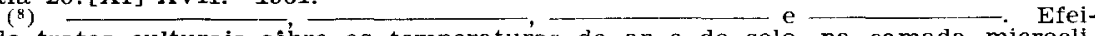
to de tratos culturais sóbre as temperaturas do ar e do solo, na camada microclimática (em pieparo). 


\title{
INJURY ON GRAFTED YOUNG AVOCADO TREES CAUSED BY HIGH TEMPERATURES
}

\begin{abstract}
SUMMARY
An injury has been observed on trunks of grafted young avocado trees in plantations of tropical regions of the State of São Paulo, with typical characteristics of sun burn. The beginning of the lesion is always noted on the side of the trunk exposed toward north, close to the grafting side. Under conditions of controlled temperature, 40 plants were tested by means of a G.E. infra-red industrial reflector. Tests were carried out with temperature at $35,40,42,44,45,48$ and $50^{\circ} \mathrm{C}$, with exposure of 120 minutes, all of them with 5 repetitions. The trunk temperature was taken with the help of thermocouples copper-constantan, $\mathbf{n}^{\circ} 30$, and of a potentiometer of Leeds and Northrup. The results obtained in the laboratory showed that the harm was lethal in the treatments at $45^{\circ} \mathrm{C}$ and that the levels of resistance of the stock and the graft differ. The former resisted to temperatures up to $45^{\circ} \mathrm{C}$ and were only harmed at the temperature of $48^{\circ} \mathrm{C}$.

Comparing these data obtained in the laboratory, with the climatic and microclimatic conditions of the regions where this fruit tree is being cultivated, the harm caused can be accounted for by the over-heating of the microclimatic layer near the surface of the soil, a fact which is normally observed in several avocado producing countries.
\end{abstract}

